\title{
A GREEN COMEBACK IN GREECE? THE ECOLOGIST GREENS IN THE 2007 PARLIAMENTARY ELECTION
}

\author{
KOSTAS GEMENIS
}

\section{BACKGROUND}

One of the most prominent features of environmental politics in Greece has been the weakness of Green political organisations (Weale et al. 2000, p. 252). The first serious Green electoral bid occurred in 1989. Helped by proportional representation and widespread discontent with the established parties (Karamichas and Botetzagias 2003, p. 73), the Ecologist Alternatives participated in the November 1989 and April 1990 elections gaining 0.6 and $0.8 \%$ of the vote respectively, and one parliamentary seat. But their success was short-lived: pronounced factionalism and the conflict over the issue of recognising the neighbouring republic as Macedonia destroyed the party organisation. The Green MP resigned from the party and became independent while the party 'withered away' (Karamichas and Botetzagias 2003, p. 87) before the parliamentary term was over.

The 3\% threshold for parliamentary representation established in 1993 made it even harder to sustain Green political organisations. Various groups have tried to earn representation in the parliament, but with little success. The last of these was Prasini Politiki (Green Politics), a member of the European Federation of Green Parties which became quite visible through its activism (Karamichas and Botetzagias 2003, p. 88). In December 2002 Prasini Politiki, along with other environmental groups and individual activists, participated in the founding congress of the Ecologist Greens. The merger of these groups into a single party opened expectations for a Green comeback in the Greek party system. Having sat out the 2004 parliamentary election, the Ecologist Greens nevertheless ran for the 2004 European Parliament (EP) election held two months later. The party did not obtain any MEPs, but the 40,873 votes $(0.67 \%)$ sustained hopes for success. In the 2006 local elections, the party selectively supported candidates in cooperation with leftist parties. It also ran independent lists in Athens and Thessaloniki and got two of its candidates elected to the Thessaloniki Prefecture Council with $4.6 \%$ of the vote.

\section{ORGANISATION AND IDEOLOGY}

The party has since built a considerable party organisation with local chapters in 18 electoral constituencies. Its chief executive body is the Executive Secretariat with six (plus two non-voting) members. Secretariat members are elected by the Panhellenic Council, the party's national political and executive organisation. Of the 34 members of the Panhellenic Council, 9 are elected by the Annual Congress and the rest by the Regional Conferences. These bodies operate under the principles

This paper is forthcoming in Environmental Politics. 
of rotation, an organisational trait the Ecologist Greens have inherited from their forerunners, the Ecologist Alternatives.

The Ecologist Greens favour a decentralised party organisation. In fact, decentralisation is one of the party's founding principles along with ecology, sustainability, participatory democracy and social justice. Although the 2003 party manifesto focussed mainly on environmental issues such as sustainable development, organic farming and food safety, renewable energy sources, biodiversity and urban planning, the party has taken positions on a wide array of issues.

For example, the party has emphasised strengthening the local administration's competencies and increasing the role of not-for-profit and non-governmental organisations in the economy. On education, it adopted a left-libertarian approach. It opposed hosting the 2004 Olympic Games in Athens, condemning them as a consumerist enterprise that would plunge the country into debt. The party's commitment to peace and non-violence was expressed in a call for abolishing NATO. In addition, the party criticized deregulating the labour market without trade union consent. On many issues the Ecologist Greens took positions similar to those of the parties of the left. This contradicted its claim to stand above the left-right distinction. Like other European Green parties, the Ecologist Greens therefore 'came to be seen as part of the left' (Mair 2001, p. 107), a feature that reduced the party's ability to cut across established partisan lines. A notable exception to this ideological orientation is the party's attitude towards the European Union. The Ecologist Greens are decidedly Europeanist in favour of an enlarged and federal EU, with a Common Foreign and Security Policy, a social and environmental Constitutional Treaty, and an EP with increased powers. Like other Green parties in Europe (Bomberg 2002), the Ecologist Greens see Europeanism as a vehicle of influencing public policy through the emergence of opportunity structures at the EU level.

\section{The 2007 ELECTION CAMPAign}

On August 16, 2007 Prime Minister Kostas Karamanlis, whose party New Democracy (Nea Dimokratia, ND) had been in power since 2004, called for an early election. The election, brought on by a financial scandal and scheduled for September 16, came six months before the end of the government's normal term. ND's chief rival was the Panhellenic Socialist Movement (PASOK) headed by George Papandreou. Other parties expected to earn representation in the legislature were the Communist Party of Greece (KKE), an electoral coalition of parties of the left, the Coalition of the Radical Left (SYRIZA) and the newcomer radical right Popular Orthodox Rally (LAOS) (see Gemenis 2008).

Having briefly considered but rejected the option of participating in an electoral coalition with SYRIZA, the party needed to run an effective independent campaign with limited financial resources. Unfortunately, the Ecologist Greens were excluded from the free publicity that comes with the participation in the evening news discussion panels. The justification was that the party had absolutely no prospect of passing the $3 \%$ threshold. At the same time, however, the media covered extensively the activities of a small party of the right, Democratic Revival. In fact the leader of Democratic Revival, Stelios Papathemelis, was invited to 'participate on equal terms with other party leaders in the televised debate, even though it was extremely unlikely that his party could win representation in the legislature' 
(Gemenis 2008, p. 97). As noted by one member of the Executive Secretariat, however, the Ecologist Greens qualified by law to publicly present their views on the state-sponsored television channels, since the party had candidates' lists in more than $75 \%$ of the constituencies. It seems, therefore, that the government's priority was to counterbalance the reputed success of the radical right LAOS by publicising Papathemelis's party as a legitimate alternative (Gemenis 2008, p. 97), rather than ensuring the fair representation of minority views in the debate.

Having limited means to present their positions to the public, the Ecologist Greens turned to other mediums such as radio and the internet. The internet has become the standard medium for disseminating information by social movement actors in Greece (Karamichas 2007, p. 527). The use of paper campaign posters, however, provoked controversy, as many party supporters questioned the initiative as being ecologically unsound. Moreover, the inclusion of candidates such as renowned poet Nanos Valaoritis, who headed the party's nationwide list, only marginally increased media exposure.

With slogans such as 'Don't paint it black, vote Green!' and 'Change the climate, vote Green!' the Ecologist Greens nevertheless managed a lively campaign centred on their policy positions. The manifesto adopted at the fifth Annual Congress in 2007 went beyond classic Green concerns to acknowledge various issues of the day, such as the higher education reforms proposed by the government the previous year. Though the Ecologist Greens had not taken a stance on higher education at the 2003 Annual Congress, under the pressure of events that culminated in a raucous student protest (see Dinas 2008, p. 602), the party was forced to acknowledge the issue and condemned the 'violent response of the government'.

Disaster struck, however, one week after the election campaign begun. The protracted forest fires that left more than half a million acres of burned land and over 65 confirmed casualties (Gemenis 2008, p. 97, Karamichas 2007) presented an opening for building greater environmental awareness. Soon, however, the discussion was reduced to a battle about which of the two major parties would be more competent to manage the crisis. Nevertheless, as became evident later, the frustrated electorate turned against both ND and PASOK. The resulting protest voting - in conjunction with the new, and more proportional, electoral law (see Gemenis 2008, pp. 95-96) that moderated the 'wasted vote' argument-helped the smaller parties, including the Ecologist Greens, to increase their share of votes.

\section{THE RESULTS}

The Ecologist Greens approached the election with a high degree of professionalism intended to differentiate the party from the marginal small political organisations, and, by presenting candidates in 54 out of 56 electoral constituencies, proved that their organisation extended all over the country. The 75,477 votes $(1.05 \%)$ earned by the Ecologist Greens in the 2007 election came as a surprise to observers, who expected sixth place to go to Democratic Revival, which, despite extensive media exposure, finished behind the Ecologist Greens (see Table 1).

Karamichas (2007, p. 531) has recently claimed that 'the Greens scored some of their highest electoral percentages in some of the electoral constituencies most devastated by the forest fires'. The election results tell a different story. The Greens fared best in the wider Athens metropolitan area (1.79\%), in the city of Thessaloniki (1.72\%) and in other primarily urban constituencies. In almost every 
TABLe 1. Results of the parliamentary elections in Greece, 2004 and 2007.

\begin{tabular}{lcccc}
\hline & \multicolumn{4}{c}{ Election date } \\
& 16 September, 2007 & 7 March, 2004 \\
& Votes \% & Seats & Votes \% & Seats \\
\hline New Democracy (ND) & 41.83 & 152 & 45.36 & 165 \\
Panhellenic Socialist Movement (PASOK) & 38.1 & 102 & 40.55 & 117 \\
Communist Party of Greece (KKE) & 8.15 & 22 & 5.89 & 12 \\
Coalition of the Radical Left (SYRIZA) & 5.04 & 14 & 3.26 & 6 \\
Popular Orthodox Rally (LAOS) & 3.8 & 10 & 2.19 & \\
Democratic Social Movement (DIKKI) & & & 1.79 & \\
Ecologist Greens & 1.05 & & & \\
Democratic Revival & 0.8 & & &
\end{tabular}

single rural municipality affected by the forest fires in southern Greece, their share of the vote was well below their national average, often below $0.5 \%$.

To be sure, the party seems to have benefited from widespread discontent and the electorate's willingness to vote for the small parties. In addition, the discourse that accompanied the forest fires crisis and highlighted, even if only superficially, some of the environmental concerns for which the Greens had long established positions may have helped as well. The electoral results are unrelated to whether constituencies or municipalities were affected by the forest fires. Instead, the aggregate data point to economic prosperity as a determinant of the Green vote: the strongest support came from the most affluent areas of Athens such as Glyfada (1.97\%), Marousi (2.08\%), Kifisia (2.34\%), Ekali (2.38\%), Filothei (2.96\%), Penteli (3.16\%) and Psychiko (3.53\%).

Though we lack survey data at the individual level with which to test the relationship between income and support for the Ecologist Greens, the election results are consistent with the theory linking economic security and support for the environment. As Inglehart (1971) notes, high income brings economic and physical security, which enables individuals to shift their value priorities from the materialist to post-materialist. The latter incorporate Green, libertarian and non-material values 'such as environmental protection [...] more direct forms of participation, equal rights for all cultural and racial groups, and openness to new forms of morality' (Knutsen 1990, p. 86). Consequently, as cross-national surveys have shown, individuals having post-materialist value priorities are more vote for Green parties (Franklin and Rüdig 1992). To be sure, high income may lead to the Green vote through other socio-demographic variables such as education. In both cases, however, the theory points to urban affluence rather than environmental damage as the determinant of Green voting.

\section{PROSPECTS FOR THE FUTURE}

As expected, the sixth Annual Congress of the Ecologist Greens in March 2008 evaluated the election and adopted a strategy for the future focussed on involvement in policy-making. The party is therefore determined to elect representatives at all levels of decision-making: local, national and supranational. 
At the European level, the Greens will emphasise the policy involvement of the European Green Party of which they are a founding member. Central to this objective is participation in the 2009 EP election with a view to passing the $3 \%$ threshold and electing one MEP. This goal is realistic given that opinion polls for the first half of 2008 signal the electorate's disposition to continue the protest voting approach of 2007 and that voting behaviour during EP elections tends to favour small parties.

Not only would electing one MEP catapult the Greens into the supranational level of governance, it would also add to their visibility and legitimacy for the next national parliamentary election. The party's sixth place in the 2007 election has caught the attention of pollsters who previously ignored its existence. At least four different polling companies have included questions about the party in their surveys. The Greens have good reasons to believe that, provided their candidate makes it to the EP, the party will have greater access to the media, more opportunities to present their policy positions and a better chance of success in national elections.

In addition, the Greens have recognised the significance of local authorities for environmental policy and decided to expand their presence at the local level. Hence they are planning to campaign vigorously in the 2010 local elections, create more local chapters and increase party membership while also building alliances with non-governmental organisations.

No matter how cautiously the strategy is planned, the Ecologist Greens will nonetheless face some crucial challenges. The first concerns the party's organisational structure in relation to its goal of increasing its visibility. Their reluctance to elect a party leader, due to their commitment to intra-party democracy, might compromise their ability to communicate their ideas to the electorate. Given that the political context in Greece favours parties with clearly identifiable leaderships, the six-member Executive Secretariat's rotation principle might be cumbersome.

The second challenge concerns the party's foreign policy positions. Like other European Green parties, the Ecologist Greens tend to be pacifist and internationalist. Some of their foreign policy positions might thus be construed as controversial by the established parties or the radical right. Such controversies may turn the attention of the electorate away from the party's policy positions on the environment or alienate a part of the electorate who might otherwise consider the Ecologist Greens for their protest vote. These two challenges should not be underestimated. Indeed it was the organisational format and a foreign policy issue that were largely responsible for the demise of the Ecologist Alternatives more than a decade ago (Karamichas and Botetzagias 2003). It remains to be seen whether the Ecologist Greens will use past lessons to avoid future mistakes.

\section{REFERENCES}

Bomberg, E., 2002. The Europeanisation of Green parties: exploring the EU's impact. West European Politics, 25 (3), 29-50.

Dinas, E., 2008. The Greek general election of 2007: you cannot lose if your opponent cannot win. West European Politics, 31 (3), 600-607.

Franklin, M.N. and Rüdig, W., 1992. The Green voter in the 1989 European elections. Environmental Politics, 1 (4), 129-159.

Gemenis, K., 2008. The 2007 parliamentary election in Greece. Mediterranean Politics, 13 (1), 95-101. 
Inglehart, R., 1971. The silent revolution in Europe: intergenerational change in post-industrial societies. American Political Science Review, 65 (4), 991-1017.

Karamichas, J., 2007. The impact of the summer 2007 forest fires in Greece: recent environmental mobilizations, cyber-activism and electoral performance. South European Society $\mathcal{E}$ Politics, 12 (4), 521-533.

Karamichas, J. and Botetzagias, I., 2003. Green party factionalism: the case of the Federation of Ecologists Alternatives (FEA) of Greece. South European Society E Politics, 8 (3), 64-92.

Knutsen, O., 1990. Materialist and postmaterialist values and social structure in the Nordic countries: a comparative study. Comparative Politics, 23 (1), 85-104.

Mair, P., 2001. The Green challenge and political competition: how typical is the German experience? German Politics, 10 (2), 99-116.

Weale, A., et al., 2000. Environmental governance in Europe. Oxford: Oxford University Press.

Kostas Gemenis, Research Institute for Law, Politics and Justice, Keele University, Keele, Staffs, St5 5BG, United Kingdom

E-mail address: k.gemenis@ilpj.keele.ac.uk 